\title{
Pengaruh Penambahan Bakteri Asam Laktat dan Pakan Sumber Energi terhadap Kandungan Nutrisi dan Fraksi Serat Silase Pelepah Sawit
}

\author{
H. Suryani, W. Wijayandari, S. Fakhri*, A. Latif, \& A. Yani \\ Program Studi Peternakan, Fakultas Peternakan Universitas Jambi \\ Jl. Raya Jambi - Muara Bulian KM 15 Mendalo Indah, Jambi Telp/Faks: 0741-582907 \\ *Corresponden author Email : sfakhri12@yahoo.co.uk \\ (Diterima : 04 Februari 2020; Disetujui : 10 April 2020)
}

\begin{abstract}
The purpose of this research was to evaluate the effects of Lactic Acid Bacteria (LAB) and the best energy-rich feed that could be combined with LAB on oil palm fronds (OPF) silage. Energy-rich feeds (molasses, rice polish, palm kernel cake (PKC), sludge and rice bran) were used and each of them was combined with $L A B$ (Lactobacillus plantarum and Lactobacillus fermentum, $10^{10} \mathrm{CFU} / \mathrm{mL}$ ). The treatments were $: P 0=O P F, P 1=O P F+L A B(5 \mathrm{ml} / \mathrm{kg}), P 2=O P F+L A B(5 \mathrm{ml} / \mathrm{kg})+$ molasses $(3 \%), P 3=O P F($ control $)+L A B(5$ $\mathrm{ml} / \mathrm{kg})+$ rice polish $(3 \%), P 4=O P F+L A B(5 \mathrm{ml} / \mathrm{kg})+B I S(3 \%), P 5=O P F+L A B(5 \mathrm{ml} / \mathrm{kg})+$ sludge $(3 \%), P 6=O P F+L A B(5$ $\mathrm{ml} / \mathrm{kg})+$ rice bran (3\%). Silages were packed in airtight transparent bottle silo (300 g capacity) and stored at room temperature. After 3 weeks, each silo was opened and sampled for physicals, nutrient and fiber analyses. Data were statistically analyzed in completely randomized design, and continued with orthogonal contrast analyses. The addition of LAB significantly $(P<0.01)$ increased crude protein $(C P)$, crude fibre $(C F)$, acid detergent fibre $(A D F)$, decreased hemicellulose but no significant effect on nitrogen-free extract $(N F E)$ and neutral detergent fibre (NDF) content of OPF silages. The addition of energy-rich feeds significantly $(P<0.01)$ increased $C F$ and $C P$, decreased NFE, NDF and hemicellulose, but no significant effects on ADF of OPF silage. The most suitable energy-rich feeds combining with $L A B$ in producing OPF silage was rice bran.
\end{abstract}

Keywords: Ensilage, energy-rich feeds, LAB, nutrient, oil palm fronds.

\section{PENDAHULUAN}

Perkebunan sawit menghasilkan berbagai macam limbah, salah satu diantaranya adalah OPF (Oil Palm Frond). Produksi OPF rata-rata dari perkebunan sawit adalah 69 ton/ha/tahun setara 20 ton $\mathrm{BK} / \mathrm{ha} /$ tahun. Jumlah produksi tersebut dapat mencukupi kebutuhan 6-8 satuan ternak (Fakhri dkk., 2006). Bila dilihat dari segi ketersediaannya maka OPF sangat potensial digunakan sebagai pakan, khususnya ternak ruminansia.

Pemanfaatan OPF sebagai pakan memiliki berbagai kendala diantaranya adalah OPF tersedia hanya pada waktu panen buah sawit dan dalam bentuk utuh yang tidak layak dikonsumsi ternak (Suryani et al., 2017). Oleh sebab itu, dalam memanfaatkan OPF sebagai pakan diperlukan teknologi yang dapat merubah OPF sehingga layak dikonsumsi dan dapat digunakan setiap saat. Salah satu teknologi yang potensial untuk digunakan adalah teknologi ensilase.

Ensilase merupakan salah satu teknik pengawetan hijauan pakan dengan prinsip dasar secepat mungkin membuat kondisi asam dan anaerob di dalam silo (Chen dan Weinberg, 2009). Pakan yang telah mengalami proses ensilase dapat disimpan dalam jangka waktu relatif lama, sehingga dapat digunakan sebagai pakan alternatif pada saat dimana ketersediaan hijauan pakan sulit diperoleh (Rukmantoro dkk., 2001). Kualitas silase diantaranya dipengaruhi oleh jenis aditif. Penambahan Bakteri asam laktat (BAL) pada pembuatan silase dimaksudkan untuk mempercepat peningkatan populasi mikroba di dalam silo sehingga dengan demikian dapat diharapkan terjadinya proses fermentasi karbohidrat (CHO) dengan cepat, yang selanjutnya akan mempercepat dihasilkannya kondisi asam dan anaerob di dalam silo (Harrison dan Blauwiekel, 1994). Kondisi asam dan anaerob di dalam silo juga dapat dilakukan dengan penambahan pakan sumber energi (kaya $\mathrm{CHO}$ ). Semakin banyak suplai $\mathrm{CHO}$ yang mudah difermentasi, maka akan semakin tinggi produk fermentasi di dalam silo, yang selanjutnya akan mempercepat dihasilkan kondisi asam dan anaerob (Utomo dkk., 2016).

Hasil penelitian Fakhri dan Depison (2008) menunjukkan silase OPF dengan aditif BAL cenderung memiliki kandungan abu dan PK lebih tinggi dan sebaliknya rendah kandungan karbohidrat (BETN dan SK). Penambahan aditif pakan sumber energi dalam bentuk padatan seperti poles dapat menurunkan SK $(31,09 \%$ vs $19,85 \%)$ dan meningkatkan BETN $(59,56 \%)$ sedangkan silase OPF yang mendapat aditif pakan sumber energi berupa liquid seperti 
molasses, cenderung memiliki kandungan PK yang rendah (6,14\%) (Fakhri dan Depison, 2008). Hal ini mengindikasikan mikroba yang ditambahkan dalam bentuk BAL saja tidak dapat berkembang dengan baik, demikian juga penggunaan pakan sumber energi baik dalam bentuk liquid maupun padatan saja juga tidak memberikan efek yang optimal terhadap kualitas silase OPF. Berdasarkan temuan tersebut, telah dilakukan penelitian dengan tujuan mengevaluasi pengaruh BAL, penambahan pakan sumber energi pada BAL, tipe sumber energi (cair dan padat) dan pakan sumber energi terbaik dikombinasikan dengan BAL pada pembuatan silase OPF.

\section{MATERI DAN METODE}

\section{Alat dan Bahan}

Bahan yang digunakan terdiri dari OPF, BAL, molasses, poles, BIS, lumpur sawit, dedak halus, katalis campuran (metal green), $\mathrm{H}_{2} \mathrm{SO}_{4}$ pekat, $\mathrm{H}_{2} \mathrm{SO}_{4} 0,3 \mathrm{~N}, \mathrm{NaOH} 40 \%, \mathrm{NaOH} 0,3 \mathrm{~N}$, $\mathrm{NaOH} 1,5 \mathrm{~N}^{4}$ dan aseton.

Alat-alat yang digunakan dalam penelitian ini antara lain mesin chopper, silo (botol transparan), hummer mill, saringan, cawan porselen, neraca analitik, penjepit, oven, eksikator, tanur, pembakar bunsen, labu destruksi, labu destilasi, destilator, pemanas listrik, labu Erlenmeyer $250 \mathrm{~mL}$ dan $500 \mathrm{~mL}$, biuret, corong, pipet, gelas ukur, batu didih, indikator campuran, soklet, kertas saring bebas lemak nomor 5, kertas saring nomor 41, sarung tangan karet, kapas bebas lemak, pinset, pelarut (kloroform), gelas piala, corong brunchner dan pompa vakum.

\section{Metode Penelitian}

\section{Rancangan penelitian}

Percobaan dilaksanakan menggunakan Rancangan Acak Lengkap (RAL) dengan 7 perlakuan dan 3 ulangan. Berikut perlakuan yang dievaluasi:

$$
\begin{aligned}
& \text { P0 : OPF (kontrol) } \\
& \text { P1 : OPF + Larutan BAL }(5 \mathrm{ml} / \mathrm{kg}) \\
& \text { P2 : OPF + Larutan BAL }(5 \mathrm{ml} / \mathrm{kg})+ \\
& \text { Molasses }(3 \% \mathrm{BK}) \\
& \text { P3 : OPF + Larutan BAL }(5 \mathrm{ml} / \mathrm{kg})+\text { Poles } \\
& (3 \% \mathrm{BK}) \\
& \text { P4 : OPF + Larutan BAL }(5 \mathrm{ml} / \mathrm{kg})+\text { BIS } \\
& (3 \% \mathrm{BK})
\end{aligned}
$$

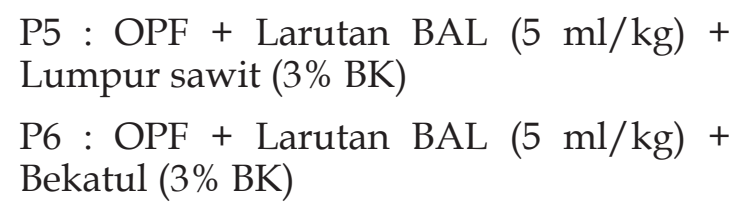

Peubahyangdiamatimeliputikarakteristik fisik, kandungan PK, SK, BETN, NDF, ADF dan Hemiselulosa silase OPF.

\section{Persiapan OPF}

OPF yang digunakan terdiri dari OPF berasal dari hasil prunning (pemangkasan) pohon kelapa sawit berumur 10-15 tahun di perkebunan kelapa sawit PTPN 6 Kabupaten Batanghari, Provinsi Jambi. OPF dicacah menggunakan chopper dengan ukuran $1-2 \mathrm{~cm}$ dan langsung digunakan untuk pembuatan silase.

\section{Persiapan Bakteri Asam Laktat (BAL)}

Bakteri Asam Laktat (BAL) yang digunakan adalah produk Fahmida Manin (FM), yang mengandung bakteri Lactobacillus plantarum dan Lactobacillus fermentum dengan konsentrasi $10^{10} \mathrm{CFU} / \mathrm{mL}$ (Manin et al., 2008).

\section{Persiapan Pakan Sumber Energi}

Pakan sumber energi yang digunakan adalah molasses, poles, BIS, lumpur sawit dan bekatul. Molasses, poles dan bekatul diperoleh di Poultry Shop Kota Jambi. BIS diperoleh dari PT. KDA dan lumpur sawit diperoleh dari PTPN 6 Kabupaten Batanghari, Provinsi Jambi.

\section{Pembuatan Silase dan Analisis Sampel}

OPF dilayukan selama \pm 1-2 hari hingga kadar air $\pm 65 \%$, kemudian dirajang sehalus mungkin menggunakan chopper. Larutan BAL dan pakan sumber energi ditimbang sesuai perlakuan. OPF dimasukkan ke dalam silo botol, lalu ditambah aditif (BAL dan pakan sumber energi) secara berlapis. Pelapisan dibuat sebanyak empat lapisan. Silo diisi sepadat mungkin, lalu botol silo ditutup rapat hingga kedap udara dan diinkubasikan selama 21 hari pada suhu ruang. Setelah 21 hari, silo dibuka dan dievaluasi keadaan umum atau kualitas fisik silase berupa warna, bau dan tekstur menurut metode Ferreira dan Mertens (2005). Sampel diambil sebanyak $10 \mathrm{~g}$ untuk pengukuran $\mathrm{pH}$ menggunakan prosedur Naumann dan Bassler (1997). Nilai fleigh dihitung berdasarkan metode Indikut et al. (2009). Sampel juga diambil sebanyak $100 \mathrm{~g}$ secara acak dari masing-masing silo, 
lalu dikeringkan dan digiling menggunakan hummer mill dengan ukuran saringan $1 \mathrm{~mm}$. Sampel selanjutnya dianalisis proksimat untuk mengetahui nilai PK, SK dan BETN (AOAC, 1995). Kandungan NDF, ADF dan Hemiselulosa dinalisis menurut metode Vant Soest (1991).

\section{Analisis Statistik}

Analisis ragam dilakukan untuk mengevaluasi pengaruh perlakuan terhadap peubah yang diamati. Apabila terdapat pengaruh yang signifikan maka dilakukan uji Orthogonal Contrast (SAS Institute Inc., 2008).

\section{HASIL DAN PEMBAHASAN}

\section{Keadaan Umum Silase OPF}

Deskripsi hasil pengamatan terhadap sifat fisik silase OPF dapat dilihat pada Tabel 1. Secara umum masing-masing perlakuan ( $\mathrm{P} 0$, P1, P2, P3, P4, P5, P6) memberikan hasil yang sama terhadap tekstur dan rasa dari silase OPF yang dihasilkan.

Tabel 1. Karakteristik fisik, $\mathrm{pH}$ dan NF silase OPF masing-masing perlakuan.

\begin{tabular}{cccccccc}
\hline \multirow{2}{*}{ Item } & \multicolumn{7}{c}{ Perlakuan } \\
\cline { 2 - 8 } & P0 & P1 & P2 & P3 & P4 & P5 & P6 \\
\hline Bau & A & A & AT & AT & AT & AB & AT \\
Warna & HK & KC & HK & KC & KC & CK & HK \\
Tekstur & L & L & L & L & L & L & L \\
Rasa & A & A & A & A & A & A & A \\
Kerusakan / jamur & 0 & $<1 \%$ & 0 & $<1 \%$ & 0 & 0 & 0 \\
pH & 3,65 & 3,56 & 3,69 & 3,75 & 3,84 & 4,01 & 3,84 \\
NF & 60 & 63 & 59 & 56 & 52 & 45 & 52 \\
\hline
\end{tabular}

Keterangan : A : Asam, AT : Asam Tape, AB : Asam Busuk, HK : Hijau kekuningan, KC : Kuning kecoklatan, CK : Coklat kekuningan, L : Lembut, P0 : OPF, P1 : OPF + Larutan BAL ( $5 \mathrm{ml} / \mathrm{kg}), \mathrm{P} 2: \mathrm{OPF}+$ Larutan BAL $(5 \mathrm{ml} / \mathrm{kg})+$ Molasses $(3 \%), \mathrm{P} 3: \mathrm{OPF}+$ Larutan BAL $(5 \mathrm{ml} / \mathrm{kg})+$ Poles $(3 \%), \mathrm{P} 4: \mathrm{OPF}+$ Larutan BAL (5 ml/kg) + BIS (3\%), P5: OPF + Larutan BAL (5 ml/kg) + Lumpur sawit (3\%), P6 : OPF + Larutan BAL (5 ml/kg) + Bekatul (3\%).

Silase yang dihasilkan pada semua perlakuan umumnya memiliki tekstur sama yaitu lembut dan jelas seperti tekstur asli. Ridla et al. (2007) menyatakan silase yang baik memiliki tekstur yang lembut, tidak berlendir dan tidak berjamur. Tekstur yang lembut ini diduga karena adanya aktivitas mikroba yang merombak karbohidrat menjadi zat-zat lebih sederhana sehingga keadaan fisik berubah. Selama proses fermentasi silase OPF berlangsung terjadi aktivitas oleh degradasi bakteri selulolitik pada OPF untuk menghancurkan selulosa oleh bantuan enzim selulase sehingga menghasilkan glukosa dan monomer lainnya. Sebagian glukosa hasil degradasi selulase akan difermentasi lebih lanjut oleh bakteri asam laktat. Oleh sebab itu, proses fermentasi silase dapat membuat tekstur silase OPF menjadi lunak.

Dalam penelitian ini, penambahan aditif memberikan pengaruh terhadap bau silase OPF. Silase OPF dengan penambahan BAL (P1) cenderung memiliki bau yang sama dengan kontrol (P0) yaitu bau asam. Sebaliknya penambahan pakan sumber energi pada silase yang mendapat BAL cenderung memiliki bau asam manis seperti tape. Bau yang beraroma asam dan manis seperti tape tersebut tercermin dengan adanya pertumbuhan BAL yang disebabkan penambahan BAL dan bahan pakan sumber energi. Bau asam yang dihasikan pada silase karena proses pembuatan silase oleh bakterianaerobyang aktif bekerja menghasilkan asam organik (Astuti et al., 2013). Silase OPF yang mendapat kombinasi BAL dan pakan sumber energi lumpur sawit (P5) cenderung memiliki bau asam yang busuk dibandingkan semua perlakuan (P0, P1, P2, P3, P4, P6). Hal ini diduga karena rendahnya produksi asam laktat, dan tinggi kadar asam butirat sehingga memberikan efek bau busuk pada silase yang dihasilkan. Keadaan ini juga tercermin dengan masih tingginya nilai $\mathrm{pH}$ yang dihasilkan oleh P5. Elferink et al. (2000) menyatakan bahwa bau busuk terjadi disebabkan oleh asam butirat dan gugus amin mudah terbang sebagai hasil fermentasi. 
Silase yang mendapat aditif (P1, P3, P4, P5) memiliki warna yang berbeda dibandingkan silase kontrol (P0). Sedangkan P2 dan P6 memiliki warna yang sama dengan P0. Perbedaan warna yang terjadi karena adanya pengaruh penambahan jenis aditif berupa pakan sumber energi, namun secara umum warna yang dihasilkan tergolong baik. Silase yang baik memiliki warna yang tidak jauh berbeda dengan warna asli, berwarna hijau dengan bau yang harum, keasaman dan rasa asam, bebas dari jamur, tekstur yang masih jelas dan halus merupakan indikasi bahwa silase tersebut adalah baik (Direktorat Pakan Ternak, 2012).

Berdasarkan nilai $\mathrm{pH}$ yang diperoleh (Tabel1), perlakuan penambahan BAL (P1) pada silase OPF menghasilkan nilai $\mathrm{pH}(3,56)$ paling rendah. Rendahnya nilai $\mathrm{pH}$ pada P1 karena penambahan BAL tanpa pakan sumber energi dapat meningkatkan kandungan asam laktat lebih tinggi. Hal ini sesuai dengan pernyataan Fakhri dan Depison (2008) bahwa sumber aditif dapat memengaruhi kualitas silase. Silase OPF yang mendapatkan larutan BAL (sumber mikroba) menghasilkan tingkat keasaman atau nilai $\mathrm{pH}$ paling rendah, mengindikasikan proses fermentasi berhasil dan kemungkinan besar silase tersebut dapat disimpan lebih lama tanpa banyak merubah kualitasnya. Penambahan kombinasi BAL dan pakan sumber energi (P2, P3, P4, P5, P6) tidak dapat menurunkan nilai $\mathrm{pH}$ lebih rendah dibandingakan kontrol (P0). Hal ini disebabkan karena silase OPF yang mendapat aditif kombinasi BAL dan pakan sumber energi memiliki buffering capacity yang tinggi dibandingkan kontrol. Buffering capacity dapat meningkat selama proses ensilase disebabkan produksi asam-asam organik seperti nitrat dan asam sulfat yang tinggi yang dapat menghambat penurunan $\mathrm{pH}$ silase (Knicky, 2005). Namun, secara umum pH yang dihasilkan oleh semua perlakuan tergolong sangat baik karena menghasilkan $\mathrm{pH}$ yang relatif asam. Hal ini didukung oleh Sandi et al. (2010) yang mengkategorikan kualitas silase berdasarkan $\mathrm{pH}$ yaitu: 3,2-4,2 baik sekali, 4,2-4,5 baik, 4,5-4,8 sedang dan lebih dari 4,8 adalah jelek.

Nilai Fleigh merupakanindekskarakteristik fermentasi silase berdasarkan nilai BK dan $\mathrm{pH}$ dari silase (Indikut et al., 2009). Berdasarkan kirteria tersebut, nilai Fleigh silase OPF kontrol (P0) dan silase dengan penambahan BAL (P1) dikategorikan baik yaitu 60-63 sedangkan silase OPF yang ditambahkan kombinasi BAL dan pakan sumber energi $\quad(\mathrm{P} 2, \mathrm{P} 3, \mathrm{P} 4, \mathrm{P} 5, \mathrm{P} 6)$ berkualitas cukup baik dengan kisaran nilai
45-59. Hal ini didukung oleh Ozturk et al. (2006) yang mengkategorikan nilai Fleigh yaitu 85-100 (baik sekali), 60-80 (baik), 40-60 (cukup baik), 20-40 (sedang) dan < 20 (sangat buruk).

\section{Pengaruh Perlakuan terhadap Kandungan Nutrisi Silase OPF}

Pengaruh penambahan BAL dan pakan sumber energi terhadap kandungan PK, SK dan BETN silase OPF ditampilkan pada Tabel 2. Analisis ragam menunjukkan perlakuan berpengaruh sangat nyata $(\mathrm{P}<0,01)$ terhadap kandungan PK, SK dan BETN silase OPF. Hasil uji kontras orthogonal menunjukkan kandungan PK (P0) berbeda sangat nyata $(\mathrm{P}<0,01)$ dengan silase OPF yang ditambahkan BAL dan BAL+ pakan sumber energi (P1, P2, P3, P4, P5, P6) kontras 1, kandungan BETN tidak berbeda nyata $(\mathrm{P}>0,05)$ (kontras 1$)$. Hasil ini mengindikasikan penambahan aditif (BAL dan pakan sumber energi) dalam pembuatan silase dapat meningkatkan PK silase OPF sebesar $29,20 \%$ yaitu dari 4,83\% (tanpa aditif) menjadi 6,24\% (dengan aditif). Peningkatan PK disebabkan karena adanya suplai PK dari BAL dan pakan sumber energi yang mana kedua aditif tersebut mengandung PK. Peningkatan PK silase rumput akibat penambahan BAL juga dilaporkan oleh Santoso dan Hariadi (2008). Namun, penambahan BAL tidak dapat menurunkan SK silase OPF $(42,86 \%$ vs $44,10 \%)$. Hal ini diduga karena penambahan pakan sumber energi + BAL memberikan kontribusi terhadap kandungan SK silase OPF. PeningkatanSKjuga dilaporkan olehSuperianto dkk. (2018) yang menyatakan kandungan SK silase limbah sayur kol yang ditambahkan dedak padi mengalami peningkatan, hal ini disebabkan karena dedak padi memiliki kandungan serat yang tinggi yaitu 30,73\%. Nilai BETN yang diperoleh pada penelitian ini lebih rendah dibandingkan dengan hasil Barokah dkk. (2017) pada silase pelepah kelapa sawit dan indigofera sampai level $60 \%$ menghasilkan BETN berkisar 49,94\%-57,00\%. Hal ini diduga bakteri pada silase OPF + BAL belum dapat menguraikan BETN sehingga tidak dapat meningkatkan kandungan BETN silase OPF. Hal ini didukung oleh Singh et al. (2009) menyatakan sifat terpenting dari BAL adalah kemampuannya untuk memfermentasi gula menjadi asam laktat. 
Tabel 2. Kandungan PK, SK dan BETN silase OPF masing-masing perlakuan.

\begin{tabular}{|c|c|c|c|c|c|c|c|}
\hline No & Kontras & PK (\%) & Ket. & SK (\%) & Ket. & BETN (\%) & Ket. \\
\hline 1 & P0 vs P1, P2, P3, P4, P5 dan P6 & 4,83 vs 6,82 & ** & 42,86 vs 44,10 & ** & 35,44 vs 34,05 & tn \\
\hline 2 & P1 vs P2, P3, P4, P5 dan P6 & 4,81 vs 6,52 & ** & 42,37 vs 44,55 & ** & 37,25 vs 33,41 & ** \\
\hline 3 & P2 vs P3, P4, P5, dan P6 & 6,73 vs 6,47 & ** & 41,70 vs 45,13 & ** & 34,60 vs 33,11 & th \\
\hline 4 & P3 vs P6 & 6,25 vs 7,23 & ** & 45,23 vs 42,61 & ** & 30,78 vs 35,36 & * \\
\hline 5 & P4 vs P5 & 6,71 vs 5,68 & ** & 48,65 vs 44,05 & ** & 30,40 vs 35,92 & ** \\
\hline$\underline{6}$ & $(\mathrm{P} 3+\mathrm{P} 6) \mathrm{vs}(\mathrm{P} 4+\mathrm{P} 5)$ & 6,74 vs 6,20 & ** & 43,92 vs 46,35 & ** & 33,07 vs 33,16 & tn \\
\hline
\end{tabular}

Rataan PK, SK dan BETN silase OPF yang ditambahkan BAL + pakan sumber energi (P2, P3, P4, P5 dan P6) berturut-turut sebesar 6,52\%, $44,55 \%$ dan $33,41 \%$ yaitu sangat nyata $(\mathrm{P}<0,01)$ lebih tinggi dibandingkan PK, SK dan BETN silase OPF yang hanya mendapatkan BAL (P1) sebesar 4,81\%, 42,37\% dan 37,25\%. Hasil ini menunjukkan penambahan pakan energi dalam menggunakan BAL sebagai starter dalam pembuatan silase OPF membuat BAL berkembang lebih baik di dalam silo, sehingga populasinya meningkat (fenomena ini perlu diteliti lebih lanjut) dan bakteri tersebut selanjutnya memberikan kontribusi terhadap kandungan PK silase. Penambahan pakan sumber energi pada penggunaan BAL dalam pembuatan silase OPF justru meningkatkan SK silase OPF. Pakan sumber energi memiliki SK yang belum didegradasi di dalam silo dan ini memberikan kontribusi terhadap tingginya kadar SK. Santoso dkk. (2009) menyatakan penambahan 3\% BAL dapat meningkatkan populasi BAL dalam silase rumput raja dari $2,00 \times 10^{5} \mathrm{CFU} / \mathrm{ml}$ (tanpa penambahan $\mathrm{BAL}$ ) menjadi $6,30 \times 10^{5} \mathrm{CFU} / \mathrm{ml}$ (penambahan 3\% BAL).

Penggunaan pakan sumber energi dalam bentuk liquid (molases, P2) menghasilkan kadar PK sangat nyata $(\mathrm{P}<0,01)$ lebih tinggi, kandungan SK lebih rendah, dan BETN tidak berbeda nyata $(\mathrm{P}>0,05)$ dibandingkan pemberian dalam bentuk tepung (P3, P4, P5, P6) (PK 6,73\% vs $6,47 \%$, SK $41,70 \%$ vs $45,13 \%$, BETN $34,60 \%$ vs $33,11 \%)$. Hal ini kemungkinan disebabkan karena molasses yang berbentuk liquid, dan tersusun atas gula sederhana dapat langsung digunakan oleh BAL di dalam silo sebagai sumber energi. Dengan demikian pertumbuhan mikroba BAL dalam silase yang mendapat sumber energi molases lebih cepat dan lebih tinggi dibanding sumber energi padat. Sebaliknya sumber energi berbentuk padat membutuhkan waktu untuk didegradasi dan digunakan oleh BAL di dalam silo.
Penggunaan bekatul sebagai sumber energi untuk BAL di dalam pembuatan silase menghasilkan silase OPF dengan nilai PK tertinggi $(7,23 \%)$, dan sangat nyata $(\mathrm{P}<0,01)$ lebih tinggi dibandingkan penggunaan poles $(6,25 \%$ PK). BAL dengan komponen utama PK (Czerkawski, 1976) akan memberikan kontribusi terhadap kandungan PK silase OPF. Penambahan bekatul sangat nyata $(\mathrm{P}<0,01)$ menurunkan SK $(42,61 \%$ vs $45,23 \%)$. Hal ini disebabkan karena BAL dapat menguraikan SK dari pakan sumber energi sehingga mampu menurunkan kandungan SK silase OPF. Kandungan BETN 30,78\% silase OPF + poles sangatnyata $(\mathrm{P}<0,01)$ lebihrendahdibandingkan bekatul $(35,36 \%)$. Hal ini diduga karena BETN poles memiliki kandungan karbohidrat yang tercerna tinggi dibandingkan dedak, sehingga BETN poles lebih mudah dimanfaatkan oleh BAL. Sebaliknya, BETN dedak memiliki kandungan karbohidrat rendah sehingga sulit dimanfaatkan oleh BAL akibatnya kandungan BETN silase OPF yang dihasilkan lebih tinggi. Juliano (1994) menyatakan poles memiliki kandungan available carbohydrates 51,10-55,00\% dan dedak 34,10-52,30\%.

Penambahan BIS menghasilkan silase OPF dengan kadar PK 6,71\%, SK 48,65\%, BETN $30,40 \%$ yaitu sangat nyata $(P<0,01)$ lebih tinggi dibandingkan dengan lumpur sawit $(5,68 \%$ PK, 44,05\% SK, 35,92\% BETN) sebagai sumber energi. Kadar PK yang dihasilkan lebih tinggi pada penambahan BIS dibanding lumpur sawit. Hal ini karena perbedaan kandungan PK kedua pakan sumber energi tersebut. Mathius et al. (2004) menyatakan bahwa BIS memiliki kandungan PK 16,33\% lebih tinggi dibanding lumpur sawit $14,58 \%$. Kombinasi BAL dan lumpur sawit dapat meningkatkan kandungan SK dan BETN silase OPF, diduga karena perbedaan kandungan SK dan BETN dari lumpur sawit dan BIS. BIS memiliki kandungan SK 36,68\%, BETN 14,78\% dan lumpur sawit memiliki kandungan SK 35,88\% 
dan BETN 16,36\%. Tingginya kandungan SK pada BIS sulit didegradasi oleh mikroba yang menyebabkan rendahnya kandungan BETN yang dihasilkan.

Penggunaan pakan asal limbah padi (bekatul dan poles) sebagai sumber energi untuk BAL dalam pembuatan silase OPF menghasilkan nilai PK 6,74\%, sangat nyata $(\mathrm{P}<0,01)$ lebih tinggi dibandingkan pakan sumber energi asal sawit (PK 6,20\%). Sementara itu, kandungan SK 43,92\% yaitu sangat nyata $(\mathrm{P}<0,01)$ lebih rendah dibandingkan sumber energi dari limbah sawit dengan SK 46,35\% dan kandungan BETN (33,07\% vs 33,16\%) tidak berbeda nyata $(\mathrm{P}>0,05)$ (kontras 6). Hasil ini mengindikasikan pakan asal padi lebih baik sebagai sumber energi untuk pembuatan silase OPF dari pada limbah sawit. Hal ini diduga karena pakan sumber energi asal sawit masih mengandung minyak yang tinggi dan rendah karbohidrat mudah larut dalam air (WSC) rendah, akibatnya BAL di dalam silo tidak berkembang dengan maksimal. Sebaliknya pakan sumber energi asal padi memiliki kandungan WSC tinggi 4,54\% (Lendrawati, 2008), dapat menstimulasi perkembangan BAL di dalam silo sehingga memberikan kontribusi terhadap kandungan PK silase OPF. Lendrawati (2008) menyatakan silase ransum komplit berbasis hasil samping sawit memiliki WSC 3,25\% lebih rendah dari silase ransum komplit berbasis hasil samping padi (WSC, 4,54\%). Apabila kandungan WSC pada bahan rendah, maka fermentasi tidak berjalan sempurna karena produksi asam laktat akan berhenti (Jones et al., 2004).

\section{Kandungan Fraksi Serat Silase OPF}

Pengaruh penambahan BAL dan pakan sumber energi terhadap kandungan NDF, ADF dan hemiselulosa silase OPF ditampilkan pada Tabel 3. Analisis ragam menujukkan perlakuan berpengaruh nyata $(\mathrm{P}<0,05)$ terhadap kandungan NDF, ADF dan hemiselulosa silase OPF. Hasil uji kontras orthogonal menunjukkan kandungan NDF silase OPF tanpa aditif (P0) tidak berbeda nyata $(\mathrm{P}>0,05)$ dengan silase OPF + BAL (P1, P2, P3, P4, P5, P6) (kontras 1). Hal ini kemungkinan penambahan aditif berupa pakan sumber energi tidak membuat mikroba BAL berkembang sehingga kemampuan mendegradasi NDF rendah oleh karena itu kedua perlakuan tidak berbeda $(76,82 \%$ vs $77,65 \%)$. Kandungan ADF dan hemiselulosa silase OPF tanpa aditif (P0) berbeda sangat nyata $(\mathrm{P}<0,01)$ dapat meningkatkan kandungan ADF dan menurunkan kandungan hemiselulosa dibanding silase OPF + BAL (P1, P2, P3, P4, P5, P6) (kontras 1). Hal ini diduga karena BAL yang ditambahkan langsung memanfaatkan bahan organik yang mudah dicerna sehingga proporsi ADF meningkat. Hasil ini didukung oleh Fariani dan Akhadiarto (2012) bahwa penambahan bakteri asam laktat terseleksi pada silase pucuk tebu dengan lama fermentasi 21 hari menghasilkan kandungan NDF dan ADF yang lebih tinggi dibanding lama fermentasi silase 7 dan 14 hari. Pada penelitian ini lama waktu inkubasi silase OPF adalah 21 hari dan menghasilkan kandungan NDF dan ADF lebih tinggi dibanding kontrol.

Tabel 3. Kandungan NDF, ADF dan hemiselulosa silase OPF masing-masing perlakuan.

\begin{tabular}{llllllll}
\hline No & Kontras & NDF $(\%)$ & Ket. & ADF $(\%)$ & Ket. & Hemiselulosa $(\%)$ & Ket. \\
\hline 1 & P0 vs P1, P2, P3, P4, P5 dan P6 & 76,82 vs 77,65 & th & 53,08 vs 56,45 & $* *$ & 22,77 vs 21,20 & $* *$ \\
2 & P1 vs P2, P3, P4, P5 dan P6 & 79,04 vs 77,38 & $*$ & 57,16 vs 56,31 & tn & 21,89 vs 21,07 & $* *$ \\
3 & P2 vs P3, P4, P5, dan P6 & 77,20 vs 77,42 & th & 58,65 vs 55,72 & $* *$ & 18,55 vs 21,69 & $* *$ \\
4 & P3 vs P6 & 76,38 vs 77,32 & th & 50,37 vs 54,67 & $* *$ & 17,33 vs 20,70 & $* *$ \\
5 & P4 vs P5 & 77,34 vs 78,36 & th & 60,01 vs 57,85 & $* *$ & 30,40 vs 35,92 & $* *$ \\
6 & (P3 + P6) vs (P4 + P5) & 76,90 vs 77,95 & th & 52,52 vs 58,93 & $* *$ & 24,38 vs 19,02 & $* *$
\end{tabular}

Keterangan ${ }^{\mathrm{tn}}$ : Tidak berbeda nyata $(\mathrm{P}>0,05),{ }^{*}$ : Berbeda nyata $(\mathrm{P}<0,05),{ }^{* *}$ : Berbeda sangat nyata $(\mathrm{P}<0,01)$, P0 : OPF, P1 : OPF + Larutan BAL (5 ml/kg), P2 : OPF + Larutan BAL ( $5 \mathrm{ml} / \mathrm{kg})+$ Molasses (3\%), P3: OPF + Larutan BAL (5 ml/kg) + Poles (3\%), P4 : OPF + Larutan BAL ( $5 \mathrm{ml} / \mathrm{kg})+$ BIS (3\%), P5 : OPF + Larutan BAL (5 ml/kg) + Lumpur sawit (3\%), P6 : OPF + Larutan BAL (5 ml/kg) + Bekatul (3\%).

KandunganNDFsilaseOPF+ pakansumber energi (P2, P3, P4, P5 dan P6) yaitu berbeda nyata $(\mathrm{P}<0,05)$, lebih rendah dibandingkan NDF silase OPF + BAL (P1) 77,38\% vs $79,04 \%$. Kandungan ADF tidak berbeda nyata $(\mathrm{P}>0,05)$ $56,31 \%$ vs $57,16 \%$. Kandungan hemiselulosa silase OPF + pakan sumber energi $(\mathrm{P}<0,01)$ lebih rendah dibandingkan hemiselulosa silase OPF + BAL $(21,07 \%$ vs $21,89 \%)$. Hal ini diduga karena pakan sumber energi menyumbangkan karbohidrat terlarut untuk mempercepat pertumbuhan BAL sehingga 
mikroba dapat berkembang dan mampu mendegradasi NDF lebih baik. Hal ini sesuai dengan pendapat McDonald et al. (1991) bahwa BAL akan bekerja optimal jika mendapatkan asupan nutrisi untuk pertumbuhan. Bahan yang kaya karbohidrat seperti gula, molases, pati berfungsi sebagai stimulan pada proses fermentasi dan merangsang perkembangan BAL dalam merombak hemiselulosa bahan.

Penggunaan pakan sumber energi dalam bentuk liquid (molases, P2) menghasilkan nilai NDF silase OPF $(77,2 \%)$ tidak berbeda nyata $(\mathrm{P}>0,05)$ dibandingkan pemberian dalam bentuk tepung (P3, P4, P5, P6) 77,42\% NDF. Kandungan ADF silase OPF dalam bentuk liquid $(58,65 \%)$ sangat nyata $(P<0,01)$ lebih tinggi dibandingkan pemberian dalam bentuk tepung yaitu 55,72\% (P3, P4, P5, P6), sedangkan hemiselulosa silase OPF $(18,55 \%)$ sangat nyata $(\mathrm{P}<0,01)$ lebih rendah 21,69\% (P3, P4, P5, P6.) Hal ini diduga karena bahan pakan berbentuk liquid (molases) dapat langsung dimanfaatkan oleh BAL sehingga nutrisi BAL akan cepat habis, perkembangan BAL hanya terjadi diawal dan menyebabkan penurunan aktivitas BAL. Hal ini sesuai pendapat Judoamidjojo dkk. (1989) bahwa laju pertumbuhan BAL dirangsang oleh asupan nutrien yang tersedia dan akan menurun akibat persediaan nutrisi berkurang sehingga aktivitas BAL berkurang dan menurunkan ADF.

Penggunaan bekatul sebagai sumber energi untuk BAL di dalam pembuatan silase menghasilkan silase OPF dengan nilai NDF (77,32\% vs 76,38\%) tidak berbeda nyata $(\mathrm{P}>0,05)$, ADF sangat nyata $(\mathrm{P}<0,01)$ lebih tinggi $(54,67 \%$ vs $50,37 \%)$, hemiselulosa sangat nyata $(P<0,01)$ lebih rendah $(22,64 \%$ vs $26,11 \%)$ dibandingkan penggunaan poles. Hal ini karena kandungan BETN dari kedua pakan sumber energi tersebut dimanfaatkan BAL untuk berkembang namun akan terjadi akumulasi ADF dari pakan sumber energi tersebut. Kandungan ADF bekatul lebih tinggi dibandingkan poles sehingga ADF silase OPF dengan penambahan bekatul lebih tinggi dibandingkan poles. Andayani (2009) menyatakan kandungan NDF dan ADF bekatul $58,16 \%$ dan 36,38\% berturut-turut. Ambreen dan Khatoon (2006) menyatakan kandungan NDF poles 39,96\% dan ADF 20,08\% (Dutta et al., 2003).

BIS sebagai sumber energi BAL dalam pembuatan silase menghasilkan silase OPF dengan kandungan NDF 77,34\% tidak berbeda nyata $(\mathrm{P}>0,05)$ dibandingkan lumpur sawit (78,56\%). Kandungan ADF 60,01\% vs 57,85\% sangat nyata $(\mathrm{P}<0,01)$ lebih tinggi dibandingkan lumpur sawit. Kandungan hemiselulosa 17,33\% vs $20,70 \%$ sangat nyata $(\mathrm{P}<0,01)$ lebih rendah dibandingkan lumpur sawit. Hal ini disebabkan kandungan BETN dari kedua pakan sumber energi tersebut dimanfaatkan BAL untuk aktifitas mendegradasi ADF silase OPF. Akan tetapi terjadi penambahan kandungan NDF dari pakan sumber energi sehingga kandungan NDF silase OPF berbeda, sedangkan hemiselulosa dari pakan sumber energi akan menambah kandungan hemiselulosa silase OPF. BIS memiliki kandungan hemiselulosa lebih rendah dibandingkan lumpur sawit (Mathius et al., 2004). Sinurat (2003) menyatakan kandungan hemiselulosa dan ADF lumpur sawit berturutturut $44,29 \%$ dan 18,48\% sedangkan, Mathius et al. (2004) menyatakan BIS memiliki kandungan hemiselulosa dan ADF 48,01\% dan 61,4\% secara berturut-turut.

Kandungan NDF pada silase OPF yang ditambahkan BAL dan pakan sumber energi asal padi memberikan nilai NDF 76,9\% tidak berbeda nyata $(\mathrm{P}>0,05)$ dibandingkan pakan sumber energi asal sawit (NDF 77,95\%) (kontras 6). Nilai persentase kandungan NDF hasil penelitian menunjukkan kecenderungan penambahan pakan sumber energi asal padi dapat menurunkan kandungan NDF dibandingkan penambahan pakan sumber energi asal sawit. Kandungan ADF pada silase OPF yang ditambahkan BAL dan pakan sumber energi asal padi memiliki kandungan nilai ADF $52,52 \%$, sangat nyata $(\mathrm{P}>0,01)$ lebih rendah dibandingkan pakan sumber energi asal sawit (ADF 58,92\%). Hemiselulosa $24,38 \%$, yaitu sangat nyata $(\mathrm{P}<0,01)$ lebih tinggi dibandingkan dengan sumber energi dari limbah sawit dengan hemiselulosa 19,02\% (kontras 6). Hasil ini mengindikasikan pakan asal limbah padi lebih baik sebagai sumber energi untuk pembuatan silase OPF dari pada asal sawit. Hal ini disebabkan kandungan ADF dari kedua perlakuan tersebut berbeda sehingga menambah kandungan ADF silase OPF sedangkan BAL dapat memanfaatkan kandungan BETN kedua perlakuan untuk pertumbuhannya. Pakan asal padi memiliki kandungan ADF lebih rendah dibandingkan pakan asal limbah sawit. Andayani (2009) dan Dutta et al. (2003) menyatakan kandungan ADF pakan asal padi $28,23 \%$ sedangkan Mathius et al. (2004) menyatakan kandungan ADF pakan asal limbah sawit 52,84\%. 


\section{KESIMPULAN}

Dari penelitian ini dapat disimpulkan bahwa penambahan BAL dapat meningkatkan kandungan PK silase OPF. Penambahan pakan sumber energi pada BAL dapat meningkatkan kualitas silase OPF. Penggunaan pakan dalam bentuk liquid sebagai sumber energi untuk BAL pada pembuatan silase OPF lebih baik dibandingkan dengan pakan dalam bentuk padat. Pakan sumber energi terbaik dikombinasikan dengan BAL pada pembuatan silase OPF adalah bekatul.

\section{UCAPAN TERIMA KASIH}

Penulis mengucapkan terima kasih kepada Direktorat Jenderal Pendidikan Tinggi KEMENRISTEKDIKTI, atas pendanaan melalui Skim Penelitian Unggulan Perguruan Tinggi (PUPT). Terima kasih juga disampaikan kepada PTPN 6 Jambi atas pengadaan pelepah sawit.

\section{DAFTAR PUSTAKA}

Ambreen, N. Q. \& S. Khatoon. 2006. Chemical Composition of Rice Polishing from Different Sources Romer Labs. Pakistan Ra Walipindi. Pakistan.

Andayani, J. 2009. Kecernaan in vitro komponen serat ransum ternak sapi yang menggunakan kulit buah jagung amoniasi. Jurnal Ilmiah Ilmu-Ilmu Peternakan. 12(3) : 129-136.

AOAC. 1984. Officials Methods of Analysis of the Association of Official Analytical Chemist. Washington.

Astuti, W.D., Y. Widyastuti, R. Ridwan, \& E. Yetti. 2013. Quality of vegetable waste silages treated with various carbohydrate sources. Media Peternakan. 36(2) : 20-125.

Barokah, Y., A. Ali, \& E. Erwan. 2017. Nutrisi silase pelepah kelapa sawit yang ditambah biomassa Indigofera (Indigofera zollingeriana). Jurnal Ilmu-Ilmu Peternakan. 20(2) : 59-68.

Chen, Y. \& Z. G. Weinberg. 2009. Changes during aerobic exposure of wheat silages. Anim. Feed Sci. Tech. 154 : 76-82.

Czerkawski, J. W. 1976. Chemical composition of microbial matter in the rumen. Journal of the Science of Food and Agriculture. 27 : 621-632.

Elferink, S. J. W. H. O., F. Driehuis, J. C. Gottschal, \& S. F. Spoelstra. 2000. Silage fermentation processes and their manipulation. In: Mannetje, L.T. Silage making in the tropics with particular emphasis on smallholders. Proceedings of the FAO electronic conference on tropical silage. 1 September to 15 December
1999.

Direktorat Pakan Ternak. 2012. Pedoman Umum Pengembangan Lumbung Pakan Ruminansia. Direktorat Jenderal Peternakan dan Kesehatan Hewan. Jakarta.

Dutta, N., K. Sharma, \& U. Naulia. 2003. Rice polishings as an economical subtittute for wheat brand as a supplement to a wheat straw diet for lactating buffaloes (Bubalus bubalis) in the Northern Plains of India. Buffalo Bulletin. 22(2) : 27-322.

Fariani, A. \& S. Akhadiarto. 2012. Pengaruh lama ensilase terhadap kualitas fraksi serat kasar silase limbah pucuk tebu (Saccharum officinarum) yang diinokulasi dengan bakteri asam laktat terseleksi. Jurnal Teknik Lingkungan. 13(1) : 85-92.

Fakhri, S., Akmal, Nelson, R. Murni, \& B.L. Ginting. 2006. Evaluasi Potensi Pelepah Sawit (Oil Palm Fronds) sebagai Pakan Ternak Ruminansia. Seminar Hasil Penelitian Fakultas Peternakan Universitas Jambi. Jambi.

Fakhri, S. \& Depison. 2008. Aplikasi Teknologi Silase dalam Pemanfaatan Pelepah Sawit sebagai Pakan Sapi pada Kelompok Tani Ternak di Kawasan Agropolitan Kabupaten Muaro Jambi. Laporan Penelitian. Lembaga Penelitian Universitas Jambi. Jambi.

Ferreira, G. \& D. R. Mertens. 2005. Chemical and physical characteristics of corn silages and their effects on in vitro. Journal of Dairy Science. 88 : 4414-4425.

Harrison, J. H. \& R. Blauwiekel. 1994. Fermentation and utilization of grass silage. J. Dairy Science. 77 : 3209-3235.

Indikut, L., B. A. Arikan, M. Kaplan, I. Gaven, A. I. Atalay, \& A. Kamalak. 2009. Potential Nutritive Value of Sweet Corn as A Silage Crop with or without Corn Ear. Dept. of Animal Science, Faculty of Agriculture. Turkey.

Jones, C. M, A. J, Heinrichs, G. W, Roth, \& V. A, Issler. 2004. From Harvest to Feed: Understanding silage management. State University Pensylvania. Pensylvania.

Judoamidjojo, M., Said, \& L. Hartoto. 1989. Biokonversi. Pusat Antar Universitas Bioteknologi Institut Pertanian Bogor, Bogor.

Juliano, B. O. 1994. The rice and its gross composition. Dalam: Rice Chemistry and Technology. Edisi ke-2. Juliano B. O. (ed). American Association of Cereal Chemist St. Paul Minnesota. USA. p. $17-57$.

Knicky, M. 2005. Possibilites to improve silage conservation. Effects of crop, ensiling tecnology and additive. The Faculty of Veterinary Medicine Andanimal Science. Uppsa.

Lendrawati. 2008. Kualitas Fermentasi dan Nutrisi Silase Ransum Komplit Berbasis Hasil Samping Jagung, Ubi kayu, Padi dan Sawit. Tesis. Institut Pertanian Bogor, Bogor.

Manin, F., E. Hendalia, \& A. Aziz, 2008. Isolasi dan 
produksi isolat bakteri asam laktat dan Bacillus sp dari saluran pencernaan ayam buras asal lahan gambut sebagai sumber probiotik. Jurnal Ilmu-ilmu Pertanian Teknologi Pertanian dan Kehutanan. 74-78.

Mathius, I. W., D. Sitompul, B. P. Manurung, \& Azmi. 2004. Produk Samping Tanaman dan Pengolahan Kelapa Sawit sebagai Bahan Pakan Ternak Sapi Potong: Suatu tinjauan. Pros. Lokakarya Nasional Sistem Integrasi Kelapa Sawit-Sapi. Badan Litbang Pertanian, Pemprov Bengkulu dan PT. Agricinal. 120-128.

McDonald, P., A. R. Henderson \& S. J. E. Heron. 1991. The Biochemistry of Silage. $2^{\text {nd }} \mathrm{Ed}$. Chalcombe Publication, Britain.

Naumann, C. \& R. Bassler. 1997. VDLUFAMethodenbuch Band III, Die chemische Untersuchung von Fûj ermîj eln. 3 rd ed. VDLUFA-Verlag. Darmstadt, Germany.

Ozturk, D., M. Kizilsimsek, A. Kamalak, O. Canbolat, \& C. O. Ozkan. 2006. Effects of ensiling alfalfa with whole-crop maize on the chemical compocition and nutritive value of silage mixtures. Asian Australian Journal of Animal Science. 19(4) : 526-532.

Ridla, M., N. Ramli, L. Abdullah, \& T. Toharmat. 2007. Milk yield quality and safety of dairy cattle fed silage composed of organic components of garbage. J. Ferment. Bioeng. 77 : 572-574.

Rukmantoro, S., B. Irawan, Amirudin, H. Hendrawan, \& N. Masayoshi. 2001. Produksi dan Pemanfaatan Hijauan. Direktorat Jenderal Peternakan. Departemen Pertanian, Dinas Peternakan Propinsi Jawa Barat dan Japan International Cooperation Agency (JICA). PT. Sony Sugema Presindo. Bandung.

Sandi, S., E. B. Laconi, A. Sudarman, K. G. Wiryawan, \& D. Mangundjaja. 2010. Kualitas nutrisi silase berbahan baku singkong yang diberi enzim cairan rumen sapi dan Leuconostoc mesenteroides. Media Peternakan. 33(1) : 25-30.
Santoso, B. B. Tj. Hariadi, H. Manik, \& H. Abubakar. 2009. Kualitas rumput unggul tropika hasil ensilase dengan aditif bakteri asam laktat dari ekstrak rumput terfermentasi. Media Peternakan. 32 : 137-144.

SAS. Institute. 2008. JMP 8 For Windows. SAS Inst. Inc., Cary. NC. USA.

Singh. S., P. Goswami, R. Singh., \& K. J. Heller. 2009. Application of molecular identification tools for Lactobacillus, with a focus on discrimination between closely related species. Food Science and Technology. 42 : 448-457.

Sinurat, A.P. 2003. Pemanfaatan lumpur sawit untuk bahan pakan unggas. Wartoza. 13(2) : 39-47.

Superianto, S., A. E. Harahap, \& A. Ali. 2018. Nilai nutrisi silase limbah sayur kol dengan penambahan dedak padi dan lama fermentasi yang berbeda. Jurnal Sains Peternakan Indonesia. 13(2) : 172-181.

Suryani, H., M. Zain, R.W.S. Ningrat, \& N. Jamarun. 2017. Effect of diertary supplementation based on an ammoniated palm frond with direct fed microbials and virgin coconut oil on the growth perfomance and methane production of Bali cattle. Pakistan Journal of Nutrition. 16 (8) : 599 - 604 .

Utomo, R., C. T. Noviandi, A. Astuti, N. Umami, L. J. M. C. Kale-Lado, A. B. Pratama, N. A. Jamiil, \& N. Sugiyanto. Penggunaan Aditif pada Kualitas Silase Hijauan Sorghum vulgare. Dalam : Prosiding Simposium Nasional Penelitian dan Pengembangan Peternakan Tropik Tahun 2016 "Pengembangan Peternakan Berbasis Plasma Nutfah dan Kearifan Lokal Mendukung Agroekologi Berkelanjutan". Fakultas Peternakan Universitas Gadjah Mada, Yogyakarta.

Van Soest, P. J., J. B. Robertson, \& B. A. Lewis. 1991. Metods for dietary fibre, neutral detergent fibre and nonstructural polysacharides in relation to animal nutrition. Journal of Dairy Sci. 74 : 3583-3597. 